\title{
KEARIFAN LOKAL SEBAGAI DAYA TARIK WISATA BUDAYA DI DESA SADE KABUPATEN LOMBOK TENGAH
}

\author{
Raodatul Hasanah \\ Universitas Negeri Yogyakarta \\ e-mail : raodatul12@yahoo.co.id \\ Diterima : 12 April 2019. Disetujui : 9 Mei 2019. Dipublikasikan : 30 Juni 2019 \\ (C2019 - DESKOVI Universitas Maarif Hasyim Latif. Ini adalah artikel dengan akses \\ terbuka di bawah lisensi CC BY 4.0 (https://creativecommons.org/licenses/by/4.0/)
}

\begin{abstract}
ABSTRAK
Desa Sade merupakan salah satu desa di Kapupaten Lombok Tengah yang memiliki berbagai kearifan lokal yang tetap dipertahankan sampai saat ini sebagai daya tarik wisata budaya. Kearifan lokal yang terdapat di Desa Sade terdiri dari Intangible dan Tangible. Metode penelitian ini dilakukan dengan deskriptif kualitatif . Teknik pengumpulan data dilakukann dengan observasi langsung, wawancara, dan dokumentasi. Kearifan lokal yang terdapat di Desa Sade sebagai daya tarik yaitu bangunan khas suku sasak, tarian Gendang Beleq, tenun, dan Peresean. Desa Sade juga dilengkapi dengan aksesabilitas, amneitas, Ancillaries, dan Community Involvement. Untuk meningkatkan kunjungan wisatwan dilakukan pengembangan tempat dan aktivitas wisata, akomodasi, akses ke tujuan tujuan wisata, sarana pendukung pariwisata, dan juga komunikasi pemasaran pariwisata. Pemasaran pariwisata dilakukan dengan merancang bauran pemasaran, bauran iklan, bauran iklan, dan harga.
\end{abstract}

Kata kunci: Kearifan Lokal, Desa Sade, Desa budaya, Wisata Budaya

\section{ABSTRACT}

Sade village is one of the villages in central lombok regency which has various local wisdom that has been maintained to date as a cultural tourism attraction.local wisdom contained in the village of sade consists of tangible and intangible. The research method used is descriptive qualitative.data collection techniques are done by direc observation, interview, and documentation. Local wisdom contained in the village of sade as a cultural tourist attraction is a typical building of sasa tribe, peresean, weaving lombok, gendang beleq dance .sade village is also equipped with accessability, aksesabilitas, amneitas, Ancillaries, and Community Involvement. To increase tourist visits conducted by the development of places and tourism activites, accommodation, access to tourist destinations, tourism support facilities, as well as tourism maeketing communications. Tourism marketiing is done by designing a marketing mix, advertising, and price.

Keywords: Local Wisdom, Sade Village, Village Culture, Culture Tourism

\section{PENDAHULUAN}

Peranan pariwisata dalam pembangunanan ekonomi di berbagai negara tidak dapat kita ragukan lagi. Sejak beberapa tahun terakhir pariwisata menjadi sektor ungggulan dalam perolehan devisa, penciptaan lapangan kerja, dan pengentasan kemiskinan. Pariwisata merupakan serangkaian kegiatan atau pergerakan yang dilakukan manusia dari tempat tinggalnya ke beberapa tempat tujuan di luar lingkungan tempat tinggalnya dengan tujuan mencari hiburan dan tidak untuk bekerja (Page, 2009: 14). Dengan berkembangnya pariwisata, maka muncullah tren pariwisata, salah satunya yaitu cultural taourism atau wisata budaya. Atraksi utamanya adalah serangkaian kegiatan kebudayaan yang bisa dinikmati tidak hanya ditonton tetapi wisatawan dapat menjadi objek dari kebudayaan tersebut. Salah satu cultural taourism yang sedang berkembang di Indonesia adalah desa wisata berbasis budaya. Menarik untuk diceramati perkembangan desa wisata berbasis budaya di berbagai daerah, khususnya di kabupaten Lombok Tengah. Perkembangan pariwisata di Kabupaten Lombok Tengah dimulai tahun 1989 dan menetapkan 15 kawasan pariwisata, salah satunya yaitu Desa Sade yang ditetapkan sebagai kawasan desa wisata. Desa Sade terletak di Desa Rembitan, merupakan salah satu dari 16 desa dalam wilayah Kecamatan Pujut. Berjarak dari ibu kota provinsi kurang lebih $45 \mathrm{~km}$, dari kota kabupaten $18 \mathrm{~km}$ dan dari ibu kota kecamatan $3 \mathrm{~km}$. Desa ini mudah dicapai karena pemerintah sendiri memberikan fasilitas infrastrukur yang memadai dengan jalan aspal, dan pembangunan bandara internasional yang terletak sekitar 10-20 menit dari Desa Sade. Desa Sade penuh dengan keistimewaan, karena desa ini menawarkan pesona khas Suku Sasak yang masih kental mulai dari adat istiadat, kesenian (tarian, musik) permainan/atraksi budaya, gaya berpakaian, dan kerajinan. Berdasarkan potensi yang dimiliki Desa Sade sebagai desa wisata diperlukan 
pengembangan dengan tujuan menjaga, melindungi, melestarikan tradisi dan kearifan lokal dengan memanfaatkan potensi demi pemberdayaan ekonomi kreatif dan pembangunan pariwisata (Perdes 052014 pasal 4). Namun di sisi lain muncul berbagai persoalan diantaranya kesiapan berbagai pihak terkait keberadaan desa wisata budaya, kemasan potensi dari daya tarik desa wisata budaya, permasalahan sarana dan prasarana, permasalahan sumber daya manusia, dan promosi yang efektif untuk menarik wisatawan berkunjung ke Desa Sade.

Berdasarkan pemaparan latar belakang di atas, maka rumusan permasalahan yaitu kearifan lokal apa saja yang ada di desa Sade sebagai daya tarik wisata budaya dan strategi yang harus dilakukan untuk menarik pengunjung agar datang ke Desa Sade

Tujuan dari penelitian ini adalah untuk mengali dan mengidentifikasi potensi kearifan lokal yang ada di desa sade, dan bagaimana strategi untuk menarik pengunjung datang ke Desa Sade.

\section{Penelitian Terdahulu}

Triwardani, Reni. (2014). Implementasi Kebijakan Desa Budaya Dalam Upaya Pelestarian Budaya Lokal.

Penelitian ini membahas tentang tantangantantangan yang di hadapai dalam mempertahankan budaya lokal dalam arus globalisasi. Metode penelitian yang digunakan yaitu deskriptif kualitatif dengan studi kasus pada desa budaya di Banjarharjo, kali bawang, Kulon progo. Variabel penelitian yaitu adat istiadat, kearifan lokal, kuliner, situs arsitekur,seni pertunjukan. hasil penenelitian yaitu pada tahapan implementasi kebijakan penetapan desa budaya sebagai model pelestarian budaya lokal perlu ditndaklanjuti dengan kebijakan tata kelola desa budaya sehingga dapat meningkatkan kesejahteraan masyarakat pelestari budaya lokal.

Dewi, made. 2013. Pengembangan Desa Wisata Berbasis Partisipasi Masyarakat Lokal Di Desa Wisata Jatiluwih Tabanan Bali.

Penelitian ini betujuan untuk mengkaji keterlibatan masyarakat lokal dalam pengembangan desa wisata dan merumuskan model pengembangan desa wisata jatiluwih tabanan, bali. Pengumpulan data dilakukan dengan studi literatur, wawancara, dan observasi non partisipan. Metode analisis adalah analisis deskriptif. Variabel penelitian ini adalah masyakarat, pemerintah, dan swasta. Hasil penelitian ini menunjukan bahwa pengembangan desa wisata di Jatiluwih belum melibatkan masyarakat lokal, peranan pemerintah dominan. Bila mengacu pada tata kelola pemerintah yang bersih dan keberlanjutan peran pemrintah diharapkan menjadi fasilitator dengan memberikan peran dan manfaat yang lebih besar pada masyarakat lokal.

Imanuel, Florentinius. (2015). Peran Kepala Desa Dalam Pembangunan Di Desa Budaya Sungai Bawang Kecamatan Muara Badak Kab Kutai Kartanegara.
Penelitian ini betujuan untuk mengetahui peran kepala desa dalam pembangunan di desa budaya sungai bawang kecamatan muara badak, kabupaten kutai kartanegara dan faktor pendukung dan penghambat dalam pembnagunan di desa budaya. Jenis penelitian adalah deskriptif kualitatif dengan fokus penelitian yaitu peran kepala desa sebgai motivator. Teknik pengumpulan data yaitu observasi, wawancara data, reduksi data, penyajian data, dan menarik kesimpulan. Hasil penelitian diperoleh yaitu kepala desa sebagai fasilitator, selalu berupaya untuk pembangunan berupa pembuatan jalan desa, irigasi, jembatan, posyandu, balai pertemuan dan sarana olahraga yang dapat digunakan masyarakat dalam melaksanakan kegiatan terutama dalam meningkatkan perekonomian.

\section{Kerangka Teori \\ Pengertian Kebudayaan}

Dalam buku Tumanggor (2013:19)

Koentjaraningrat mengatakan bahwa kebudayaan itu merupakan sebuah wujud yaitu sebagai culture system, social system, dan artefac. Menurut oka A yoeti (2006: 22) kebudayaan adalah sebuah entitas yang dapat dipengaruhi oleh faktor-faktor sosial dan lingkungan hidup. Menurut Yunus (2012:21) kebudyaan adalah nilai-nilai yang diwariskan secara turun temurun dari generasi ke generasi berikutnya berupa nilai nilai solidaritas. Artinya dapat disimpulkan bahwa kebudayaan itu tersusun dari komponen yang bersifat kognitif, normatif, dan material, sehingga antara manusia terjalin hubungan yang erat karena manusia merupakan hasil dari kebudayaan tersebut. Dalam perspektif yang lebih luas kebudayaan diartikan sebagai suatu sistem yang didalamnya terdapat normanorma, nilai-nilai tentang hubungan sosial dan perilaku yang menjadi identitas dari masyarakat bersangkutan. Sebagai sebuah sistem, kebudayaan perlu ditinjau dari perwujudan kehidupan manusia yang terhubung dengan ide, perilaku, dan hasil cipta karsa (sejarah, tradisi, adat istiadat, bahasa) yang dipengaruhi oleh berbagai aspek. Pada konferensi UNESCO disebutkan bahwa budaya tidak hanya diartikan sebagai sebuah seni pertunjukan, namun mencakup pengertian yang luas sebagai sebuah identitas pada sebuah kelompok, suku atau bangsa.

Budaya merupakan cara hidup yang dimiliki oleh sebuah kelompok orang dan diwariskan dari generasi-kegenerasi berikutnya. Singkatnya, kebudayaan adalah hasil dari karya manusia yang tetap mempertahankan cara hidup, dan proses adaptasi dengan lingkungannya. Dijelaskan dalam undangundang pariwisata nomor 09 tahun 1994 bahwa pengembangan pariwisata di indonesia menggunakan konsep kepariwisataan yang bertumpu pada kebudayaan yang berlandaskan pancasila, sehingga diharapkan setiap pengembangan pariwisata selalu bertumpu pada kebudayaan bangsa indonesia. Budaya sangat penting perannya dalam pariwisata, dan menjadi salah satu faktor utama untuk menarik wisatawan untuk melakukan perjalanan wisata. Kebudayaan yang 
dimiliki oleh bangsa indonesia memiliki potensi khusus untuk menarik wisatawan berkunjung. Dengan melakukan perjalanan wisata budaya wisatawan dapat melihat cara hidup dan budaya orang lain, sehingga akan timbul keinginan untuk mempelajari budaya tersebut, dan mereka tidak hanya sekedar bersantai untuk mendapatkan hiburan tetapi mendapatkan value berupa pengalaman sebagai sebuah pengetahuan baru melalui berwisata budaya. Pariwisata budaya merupakan salah satu pariwisata yang bertujuan pada tempat, tradisi, kesenian, upacara-upacara, dan pengalaman yang memotret bangsa/suku bangsa, yang merefleksikan keanekaragaman dan identitas dari masyarakat atau bangsa bersangkutan. Selaras dengan Organisasi wisata dunia (world tourism organization) mendefinisikan pariwsata budaya adalah kegiatan untuk menikmati sejarah alam, peninggalan budaya manusia, kesenian, filosofi, dan pranata dari wilayah lain. Secara konseptual pengembangan pariwisata berbasis sumberdaya budaya bertujuan untuk mendukung upaya-upaya pelestarian budaya dan lingkungannnya. Caranya adalah melalui peningkatan partisipasi masyarakat dalam memanfaatkan secara berkelanjutan sumberdaya budaya sebagai daya tarik pariwisata guna meningkatkan taraf hidup dan ekonomi masyarakat setempat.

\section{Pengertian Pariwisata}

Menurut undang-undang nomor 09 tahun 2009 pasal 1 pariwisata adalah berbagai kegiatan wisata yang didukung oleh berbagai fasilitas dan pelayanan yang disediakan oleh masyarkat, pengusaha, pemerintah, dan pemerintah daerah. Menurut situs www.worldtoursim.org dalam buku Page (2009: 14), pariwisata adalah aktivitas perjalanan yang dilakukan untuk berpergian dari tempat tinggalnya ke tempat lain, dengan tujuan hiburan, dan bukan untuk pekerjaan. Dari pernyataan tersebut maka dapat disimpulkan bahwa pariwisata adalah kegiatan manusia yang dilakukan secara sadar untuk melakukan perjalanan guna mendapatkan hiburan, edukasi, dan kesenangan.

Menurut Cahyadi dan Gunawijaya (2009: 1) pariwisata merupakan industri yang paling besar di dunia saat ini, dilihat dari orang yang terlibat maupun uang yang beredar didalamnya. Bersama dengan sektor pertanian dan sektor industri manufaktur, pariwisata adalah ujung baru tombak perekonomian dunia yang terbentuk dari 7 unsur yaitu

a. Informasi wisata

b. Biro perjalanan

c. Transportasi

d. Aksesabilitas

e. Destinasi wisata

f. Atraksi wisata

g. Unsur penunjang ( pendidikan pariwisata dan pemasaran.)

\section{Kearifan lokal (Pusaka Budaya)}

Kearifan lokal menurut Sedyawati (2012:382) adalah berbagai pola, tindakan dan hasil budaya material yang dijabarkan dalam seluruh warisan budaya baik tangible maupun intangible. Yunus, (2012:37) menjelaskan kearifan lokal adalah kebudayaan yang dimiliki oleh masyarakat tertentu di tempat tertentu untuk mempertahankan diri dari arus global dan sebagai sebuah jati diri. Di tinjau dari struktur kearifan lokal merupakan sebuah culture. Dimana hal ini didasarkan pada masyarakat indonesia yang majemuk dan multikultural, sehingga dapat disimpulkan bahwa kearifan lokal adalah sebuah pandangan hidup yang berwujud akitvitas yang di wariskan turun temurun.

Kearifan lokal merupakan sebuah tradisi yang harus dikembangkan, digali, dan dilestarikan karena didalamnya terdapat nilai-nilai yang sangat universal dan terbentuk sebagai keunggulan budaya masyarakat setempat. Disebutkan oleh Ayatrohaedi (1986: 41) bahwa ciri-ciri masayarakat tetap mempertahankan kearifan lokal sebagai sebuah potensi yaitu sebagai berikut:

a. Mampu bertahan terhadap pengaruh budaya luar (asing)

b. Mempunyai kemampuan memenuhi unsur-unsur budaya luar

c. Memiliki kemampuan menyatukan unsur budaya luar ke dalam budaya asli

d. Memiliki kemampuan mengendalikan

e. Dapat memberi tujuan pada perkembangan budaya Kearifan lokal yang tetap dipertahankan merupakan ciri dari sebuah msayrakat yang menghargai dan mencintai warisan budaya. Dan potensi kearifan lokal yang terbentuk dari budaya saat ini menjadi sebuah potensi pariwisata yang sangat menjanjikan seperti yang diungkapkan Cahyadi dan Gunawijaya (2009:4) bahwa pariwisata pusaka budaya yang tetap melestarikan budaya lokal adalah industri pariwsata yang paling maju perkembangnya. Karena wisatawan selain mendapatkan hiburan juga mendapatkan pengetahuan, dan pengalaman budaya serta kenyamanan yang dapat membuatnya datang kembali.

Walker (1996) dalam buku Cahyadi dan Guanwijaya menyebutkan ada beberapa manfaat dari pengembangan pariwisata pusaka yaitu

a. Ekonomi

- Tersedianya kesempatan kerja

- Keragaman lapangan kerja

- Meningkatkan pendapatan penduduk daerah

b. Fisik

- Mempertahankan bangunan bersejarah dan pusaka budaya

- Peningkatan infrastruktur

- Meningktnya upaya-upaya konservasi

c. Sosial flora,fauna dan ekosistemnya

- Dikenalnya masyarakat tujuan wisatawan

- Meningktnya upaya menjaga nilai-nilai budaya setempat

- Menigkatnya kebanggaan warga dan meningkatnya kesempatan pendidkan yang lebih tinggi 
- Menbantu masayarakt menegenal keunikan mereka.

\section{Daya tarik wisata budaya}

Daya tarik pariwisata menurut undang undang nomor 10 tahun 2009 disebutkan bahwa segala sesuatu yang mempunyai keunikan, keindahan, kemudahan dan keanekaragaman kekayaan alam, budaya dan hasil buatan manusia yang menjadi tujuan kunjungan wisatawan. sumber daya budaya tersebut seperti kesenian, sejarah, dan kearifan lokal yang merupakan modal pembangunan kepariwisatan budaya. Menurut yulianto, dalam jurnal media wisata 1 mei 2015 menjelaskan beberapa konsep perencanaan daya tarik wisata yaitu:

a. Melakukan Pengelolaan terhadap sarana dan prasarana pariwisata

b. Melakukan pengelompokan kunjungan wisatawan dengan wisatawan pelengakap

c. Gabungan atraksi dan dukungan pelayanan

d. Melakukan pengontrolan dan perencanaan terhadap daya tarik wisata yang masih alami.

\section{METODE PENELITIAN}

Metode yang digunakan pada penelitian ini yaitu jenis penelitian deskriptif kualitatif. Menurut Moleong penelitian kualitatif adalah metodelogi yang dikumpulkan dari kata-kata,gambar, dan bukan angka (Moleong, 2014:11). Teknik pengumpulan data pada penelitian ini dilakukan dengan beberapa teknik yaitu:

\section{Observasi}

Menurut Herdiansyah, (2010) dalam Herdiansyah Haris, (2013: 31) observasi adalah teknik pengumpulan data melalui proses melihat, mengamati, dan mencermati serta merekam prilaku secara sistematis. Penulis melihat dan mengamati kegiatan-kegiatan dan kondisi yang ada di Desa Sade secara langsung untuk menjaring data agar dapat di simpulkan sesuai dengan data yang dibutuhkan.

\section{Wawancara}

Menurut Moleong (2001: 135) wawancara adalah percakapan yang dilakukan oleh dua orang yang salah satunya sebagai pewawancara dan yang lainnya memberi jawaban atas pertanyaan tersebut. Penulis melakukan wawancara terhadap pengelola dan wisatawan yang datang berkunjung ke Desa Sade

\section{Dokumentasi}

Dokumen bisa berupa bahan tertulis yang berhubungan dengan aktivitas tertentu. seperti arsip, surat menyurat, gambar, rekaman, dan benda peninggalan yang berkaitan dengan suatu peristiwa (Imam Suprayogo 2001: 164) dalam (Mahmud, 2011: 184). Dokumentasi dilakukan untuk mendapatkan gambar berbagai ragam kearifan lokal Desa Sade sebagai daya tarik.

\section{PEMBAHASAN}

\section{Sejarah Desa Sade}

Menurut para tertua desa, Desa sade mulai didiami penduduk pada tahun 1079. Kata sade sendiri berasal dari sansekerta yaitu 'noer sade' yang memiliki arti 'cahaya obat' dan berganti menjadi sade sejak islam masuk pada abad ke 17. Desa sade terletak Terletak pada 8'241 - 8'571 LS dan 116'051 - 116'241 BT pada ketinggian 120-126 mdpl (Badan stastitik kabupaten lombok tengah 2013). Pekerjaan utama masyakarat Desa Sade adalah bertani dan membuat kerajinan tangan seperti menenun. Tenun yang dihaslkan dibuat oleh wanita-wanita di Desa Sade sejak umur 9-10 tahun sampai menikah. Kegiatan ini dilakukan turun temurun. Sistem kepercayaan yang dianut oleh suku sasak di Desa Sade adalah Wetu Telu atau tiga waktu. Artinya masyarakat suku sasak di Desa Sade hanya menjalankan sholat tiga waktu, namun perkembangnya saat ini sudah banyak yang melaksanakan shalat 5 waktu.

Desa sade tetap mempertahankan budaya suku sasak asli dilakukan guna kepentingan pariwisata dan sekaligus merupakan bentuk dari tindakan pelestarian kebudayaan Lombok. Upaya ini didukung penuh oleh masyarakat setempat sehingga mereka ikut andil dalam pengembangan dan pelestarian budaya lokal (pusaka) sampai saat ini. pelestarian budaya lokal ini pun menjadi salah satu upaya peningktan perekonomian penduduk setempat, membuka lapangan kerja, dan meningkatan penadapatan daerah. Kearifan budaya lokal yang tetap diperthankan menjadi daya tarik tersendiri bagi wisatawan domestik dan mencangeara yag berkunjung ke lombok khususnya ke Desa Sade.

\section{Fasilitas Desa Sade}

Fasilitas pendukung merupakan salah satu unsur penting dalam pengembangan pariwisata. salah satu unsur penting dalam upaya meningktkan arus wisatwan adalanya tersedianya akomodasi yang memadai baik secara kualitas maupun kuantitas. Fasilitas-fasilitas pendukung desa sade dijelaskan sebagai berikut:

1. Aksesabilitas

Aksesabilitas adalah sarana penunjang yang dibutuhkan bagi setiap destinasi wisatawan. dengan adanya akses ke destinasi tersebut akan memudahkan pengunjung untuk datang. Akses menuju desa sade sudah sangat baik dengan fasilitas aspal dan terletak di pinggir jalan sehingga memudahkan wisatawan yang akan berkunjung. Jarak dari bandara internasional ke desa sade juga cuku dekat, dengan menggunakan taksi atau kendaraan pribadi akan dapat ditempuh dalam waktu 20 menit saja.

\section{Amenitas}

Amenitas adalah faslitas pendukung yang dibutuhkan guna menunjang wisatawan berkunjung ke desa sade. seperti hotel, transportasi, rumah makan. Namun fasilitas penunjangnya sangat minim, belum ada pembangunan home stay, dan hanya ada beberapa 
restauran, dan ada beberapa minimarket yang pelayanannya juga belum maksimal.

3. Ancillaries

Adalah fasilitas pendukung yang sangat dibutuhkan oleh wisatawan seperti warung-warung kecil dan tourist information centre yang sudah tersedia , sebagai fasilitas penunjang yang siap menjelaskan apapun tentang Dusun Sade.

4. Community Involvement.

Merupakan salah satu wujud kesadaran penyelenggara kegiatan pariwisata untuk melibatkan masyarakat lokal Desa Wisata Dusun Sade untuk berpartisipasi dalam perencanaan, pelaksanaan, dan pengelolaan Desa Wisata. salah satu bentuk kontribusi pengelola yaitu adanya home industry tempat masyarakat menjual cinderamata seperti tenun, pernak pernik berupa cincin, gelang, dan kalung.

\section{Ragam kearifan lokal Desa Sade sebagai desa wisata}

Warisan budaya yang dimiliki oleh desa sade sebagai daya tarik wisata budaya yaitu masih tetap mempertahankan cara hidup dan keahlian dari nenek moyangnya seperti mempertahankan bangunan yang masih menggunakan dinding berbahan anyaman bambu (bedek), tiang dan pakunya juga terbuat dari kayu bambu dengan atap dari daun alang-alang, dan lantai yang terbuat dari tanah liat yang dicampur dengan abu jerami dan kotoran kerbau.

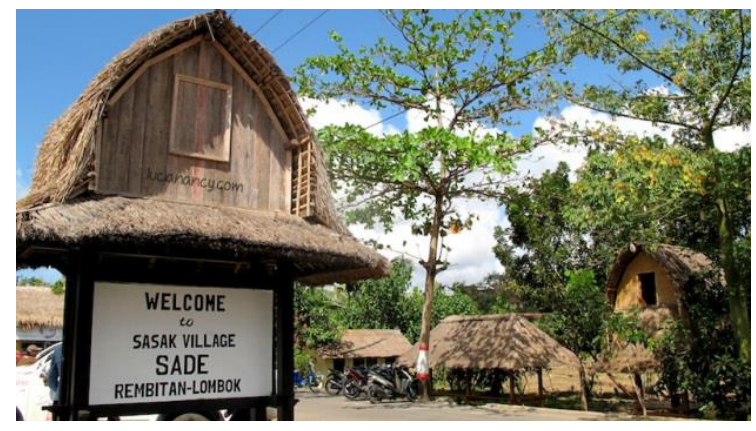

Gambar 1. bangunan/ rumah adat desa sade ( Sumber: lucianancy.com )

Penggunaan kotoran kerbau ini menurut kepercayaan masyarakat desa sade berfungsi untuk membersihkan lantai dari debu, dan membuat lantai menjadi halus dan lebih kuat. Dipercaya juga bahwa penggunaan kotoran kerbau tersebut dapat mengusir serangga dan menolak kekuatan jahat yang ditunjukan kepada pemilik rumah. Bagian dalam dari rumah adat ini terbagi menjadi tiga bagian, bagian depan yang dipergunakan untuk tidur anak laki-laki dan orang tua. Bagian kedua dipergunakan untuk dapur, lumbung, dan tidur anak perempuan. Dan bagian terakhir yang digunakan untuk tempat melahirkan oleh sang ibu.

Menurut pak Sumidah, (wawancara Agustus 2015) Rumah adat di Desa Sade ini disebut dengan
Bale, Bale Dibagi lagi menjadi 7 jenis sesuai dengan fungsinya yaitu:

a. Bale Tani

Bale tani berbentuk limasan yang ditempati oleh masyarakat suku sasak yang memiliki profesi sebagai petani. Bale tani berlantaikan tanah, dan terdiri dari beberapa ruangan. Ruangan tersebut yaitu sesangkok, Dalem bale, dan Pawon.

b. Bale Jajar

Bale jajar yaitu bale yang ditinggali oleh masyarakat suku sasak yang tergolong dalam ekonomi menengah ke atas. Bentuknya hampir sama dengan bale tani. Bale jajar mempunyai dua kamar tidur(dalem bale), serambi, dan bagian depan rumahnya biasa terdapat beruqaq.

c. Berugaq

Berugaq mempunyai bentuk segi empat sisi tanpa dinding, penyangganya terbuat dari kayu, bambu dan alang-alang sebagai atapnya. Biasanya berugaq terdapat pada samping kiri bale tani yang digunakan sebagai tempat menyinpan padi dan digunakan sebagai tempat menerima tamu untuk pemuda yang datang midang.

d. Sekenam

Yaitu bale yang bentuknya hampir sama dengan Berugaq/Sekepat, sekenam mempunyai tiang sebanyak enam buah dan biasanya dibangun di belakang rumah. Digunakan sebagai tempat kegiatan mengajar, penamanan nilai-nilai budaya dan sebagai tempat pertemuan internal keluarga.

e. Bale Bontar

Yaitu bangunan tradisional Sasak yang umumnya dimiliki oleh para Perkanggo/Pejabat Desa, dusun/kampung. Bale Bontar dipergunakan sebagai tempat persidangan adat, seperti: tempat penyelesaian masalah pelanggaran hukum adat, dan tempat penyimpanan benda-benda bersejarah atau pusaka warisan keluarga.

f. Bale Beleq Bencingan

Bale Beleq diperuntukkan sebagai tempat kegiatan besar kerajaan sehingga sering juga disebut Bencingah. Adapun upacara kerajaan yang biasa dilakukan di Bale Beleq diantaranya yaitu pelantikan pejabat, pengukuhan kiai penghulu, dan sebagai tempat penyimpanan pusaka berupa dokumen-dokumen bersejarah.

\section{g. Bale Tajuk}

Yaitu salah satu sarana pendukung bagi bangunan rumah tinggal yang memiliki keluarga besar. Bale Tajuk berbentuk segi lima dengan tiang berjumlah lima buah. Tempat ini dipergunakan sebagai tempat pertemuan keluarga besar dan pelatihan Macapat Takepan, untuk menambah wawasan dan tata krama.

Kehidupan Masyarkat di desa sade jauh dari modernisasi, mereka masih mempertahankan kehidupan tradisional yang masih kental sebagai salah satu wujud cinta akan peninggalan nenek moyang. Aktivitas yang dilakukan para masyarakat desa sade rata-rata berprofesi sebagai petani, dan perempuannya sebagai ibu rumah tangga ddengan pekerjaan 
sampingan yaitu sebagai penenun. Hasil tenunan dari perempuan-perempuan di Desa sade ini menjadi salah satu kain tenun khas lombok yang menjadi primadona cinderamata wisatawan yang berkunjung ke desa sade yang proses pembuatnya masih menggunakan bahanbahan alam untuk pewarnaanya.

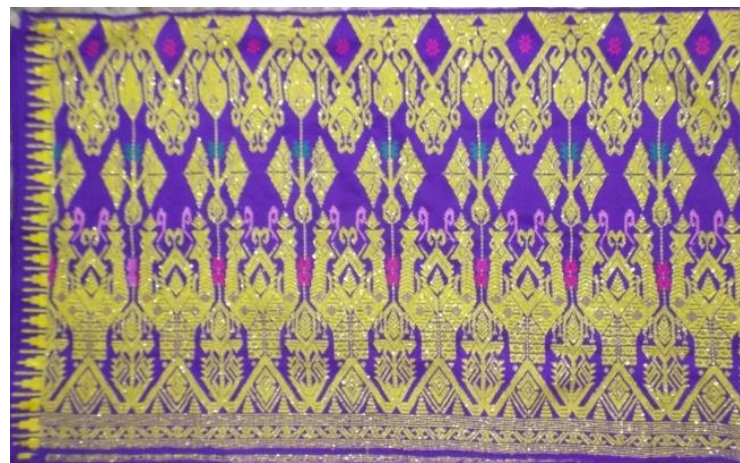

Gambar 2. Songket

( Sumber: dokumentasi Raodatul )

Selain tenun para masyarakat Desa Sade juga mempunyai kesenian dan tradisi budaya sasak yang masih kental. Kesenian tradisional yang bisa disaksikan jika berkunjung ke Desa Sade yaitu tarian Gendang Beleq. Tarian Gendang Beleq ini awalnya hanyalah tarian pengiring yang melepas prajurit kemedan perang. Tapi seiring berjalannya waktu tarian ini digunakan sebagai hiburan yang dipertunjukan pada acara kebudayaan, kesenian, atau perayaan pernikahaan di pulau Lombok.

Menurut sejarah sebelum zaman kerajaan Selaparang, yaitu masa pemerintahan Anak Agung tarian Gendang Beleq digunakan untuk memohon kesejahteraan pada saat musim tanam, dan upacaraupacara lainnya namun seiring berjalannya waktu tarian Gendang Beleq ini menjadi tarian yang mengiringi prajurit saat akan berjuang ke medang perang. Gerakan dan Suara yang dihasilkan dipercaya membuat para prajurit menjadi lebih berani untuk berkorban membela kerajaan dan dijadikan tarian musik peperangan (Ariani,dkk :2012:23). Tarian Gendang Beleq menurut para suku yang hidup di Lombok memiliki filosofi keindahan, ketekunan, kesabaran, kebijakan, ketelitian dan kepahlawanan.

Pada pertunjukan Tarian Gendang Beleq ada alat-alat musik lain yang mengiringnya seperti gendang mame, gendang nine, terumpang, gong, kenceng, suling,oncer, pencek, dan alat pemukul dan penabuh dimana alat alat tersebut membantu dalam kegiatan Penari. Tari Gendang Beleq berjumlah 13 sampai 17 orang menunjukan jumlah rakaat dalam shalat. Para penari biasa disebut Sekaha terdiri dari dua penari utama menggunakan baju adat tradisional Lombok berserta sapu (ikat kepala khas lombok). Tarian Gendang Beleq ditarikan dengan cara gerakan melangkah yang mengambarkan keberangkatan ke medan perang. Kemudian dilakukan gerakan membuka pintu yang menandakan sudah keluar dari istana dan bersiap untuk berperang. Selanjutnya gerakan waspada dengan menoleh ke kiri dan kekanan, hinggga kemudian gerakan yang dilakukan ketika berperang dan gerakan selesai berperang.

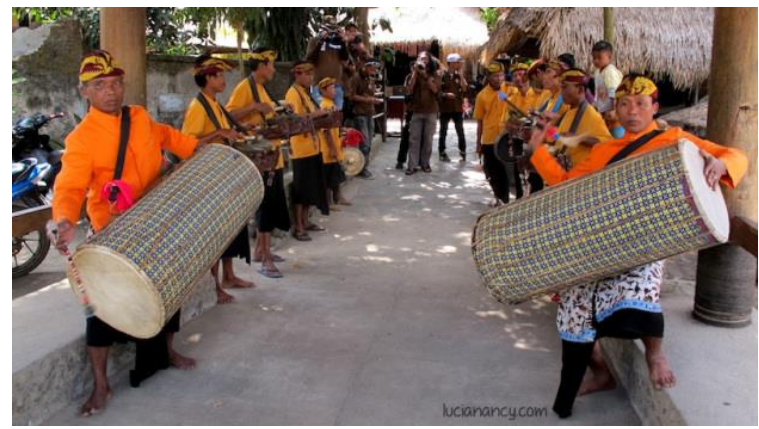

Gambar 3. Tari Gendang Beleq

Sumber: lucianancy.com

Kesenian lain yang menarik untuk kita saksikan di Desa Sade yaitu Kesenian Peresehan, menurut Wikipedia.com, Februari 2018) Peresean adalah pertarungan antara dua lelaki yang bersenjatakan tongkat rotan (penjalin) dan berperisai kulit kerbau yang tebal dan keras. Tradisi ini termasuk dalam seni tari daerah Lombok. Konon menurut cerita peresahan merupakan ajang yang digelar untuk melatih ketangkasan, ketangguhan, dan keberanian dalam bertarung mengusir penjajah. Peresahan juga menurut kepercayaan masyarakat suku sasak digunakan sebagai upacara memohon hujan di saat kemarau, sehingga pergelaran peresean ini sering kali sampai saat ini di lakukan saat musim kemarau dengan tujuan agar hujan turun. Namun kini peresean juga digelar untuk menyambut wisatawan yang berkunjung ke Desa Sade.

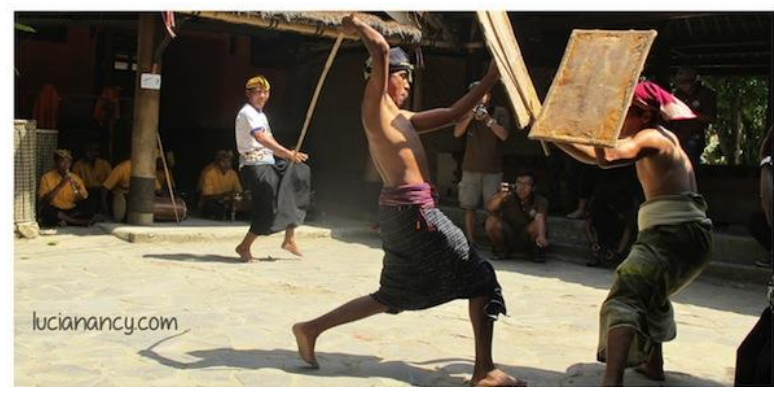

Gambar 4. Persean

( Sumber: lucianancy.com )

\section{Strategi promosi untuk menarik kunjungan wisatawan}

Keberlangsungan desa sade sebagai desa wisata membuktikan bahwa peran para aktor pelaksana yang terlibat sudah sangat baik dalam rangka pengembangan potensi pelestarian budaya lokal. Ada 3 aspek pengembangan desa sade yaitu sumber daya alam, kelembagaan, dan pemasaran.Pengelolaan pariwista sendiri dapat berperan strategis untuk beberapa fungsi yaitu perlindungan pada sumber daya alam 
keberlanjutan ekonomi, peningkatan integritas budaya dan nilai dari pendidikan dan pembelajaran.

\section{Pemasaran pariwisata}

Pemasaran menurut Kotler dan Keller (2009: 247) adalah ilmu untuk memilih sasaran pasar, mendapatkan, mempertahankan, dan menumbuhkan pelanggan melalui penciptaan, penyampaian dan pengkomunikasian nilai yang unggul kepada pelanggan. Dalam strategi pemasaran pariwisata langkah penting yang harus dilakukan adalah segmentasi pasar, penentuan pasar,sasaran,positoning dan branding. Segmentasi pasar adalah proses menggolongkan konsumen ke dalam kelompok kelompok berdasarkan kebutuhan yang berebeda, perilaku dimana setiap keolompok bisa ditentukan sebagai pasar sasaran yang akan diraih. Setelah segmentasi pasar diidentifikasi, diharapkan bisa memberikan pandangan bahwa wisatawan mempunyai karakteristik masing-masing dan saling mengguntungkan. Strategi pemasaran yang dapat dibuat meliputi pengembangan tempat dan aktivitas wisata, akomodasi, akses ke tujuan tujuan wisata, sarana pendukung pariwisata, dan juga komunikasi pemasaran pariwisata yang ditunjukan mempunyai kualitas yang tinggi akan value yang diberikan, maka usaha pengembangan desa wisata merupakan strategi yang tepat untuk diarahkan pada segmen tersebut.

Pengembangan kawasan wisata diperlukan formulasi startegi yang tepat untuk dijalankan oleh pengelola kegiatan kawasan wisata. Dengan melihat potensi yang ada desa wisata tersebut. Strategi pemasaran menduduki peran yang sangat penting dalam pembangunan pariwisata yang berkelanjutan. Utama I (2017:238) menjelaskan bahwa untuk melakukan aktivitas pemsaran beberapa hal perlu dilakukan yaitu

a. merancang bauran pemasaran untuk target pasar yang dituju,

b. bauran produk harus diranncang untuk memenuhi harapan dari taget pasar, dan kebijakan harga

c. kebijakan harga yang ditempuh harus dapat menjamin tercapainya tujuan perusahaan dan terpeliharanya kualitas lingkungan

d. bauran iklan dan promosi untuk membangun citra positif bagi produk dan destinasi yang dituju

e. melakukan kebijakan intermediasi atau bauran pemasaran

Selanjutnya Utama, I (2017 : 239-240) menjelaskan secara spesifik strategi pemasaran destinasi dibagi menjadi dua kelompok yaitu strategi promosi dan strategi fasilitas. Strategi promosi meliputi pelaksanaan program-program promosi, sedangkan strategi fasilitas yaitu membnagun kerja sama antara pengelola destinasi pariwsata dan pembisnis untuk merancang kebijakan anggaran pemasaran. Dengan adanya startegi tersebut diharapka Pengembangan pariwisata akan menjadi salah suatu upaya meningkatkan pembangunan mutu menuju sasaran yang dikehendaki. terkait hasil pertanian, home industry, serta pendidikan untuk memenuhi Sumber daya manusia ( Yoeti: 2016).

\section{KESIMPULAN}

pada penelitian ini kearifan lokal sebagai daya tarik wisata budaya di desa sade kabupaten lombok tengah disimpulkan hasil penelitian yaitu di desa sade terdapat kearifan lokal yang merupakan hasil dari kebudayaan yang masih dilestarikan sebagai daya tarik pariwisata seperti bangunan khas suku sasak, peresean, tenun khas lombok, dan tarian gendang beleq. Dan kearifan lokal yang bisa di saksikan di desa sade adalah masayarakatnya masih mempertahankan cara hidup dari peninggalan nenek moyangnya. Setiap daya tarik yang ada di desa sade tentunya membutuhkan cara untuk mendatangkan wisatawan untuk berkunjung yakni melalui bauran pemasaran, bauran iklan, bauran, produk, serta pengembangan tempat dan aktivitas wisata, akomodasi, akses ke tujuan tujuan wisata, sarana pendukung pariwisata komunikasi pemasaran pariwisata melalui media masa. Berbagai kearifan lokal yang masih dilestarikan di desa sade merupakan daya tarik wisata budaya. Kearifan lokal yang dimiliki desa sade memberikan dampak postif terhadap masyarakat sekitar seperti membuka lapangan kerja, dan meningkatan pendapatan daerah.

\section{DAFTAR PUSTAKA}

Cahyadi, Rusli, Gunawijaya, Jajang. (2009). Pariwisata Pusaka (Masa Depan Bagi Kita, Alam Dan Warisan Budaya Bersama). Jakarta: UNESCO Bekerjasama Dengan Vokasi Pariwisata UI

Herdiansyah, Haris. 2013. Wawancara Observasi dan Fokus Groups Sebagai Intrumen Penggalian Data Kualitatif. Jakarta: PT Rahagrafindo Persada

Mahmud. 2011. Metode Penelitian Pendidikan. Bandung: Cv Pustaka Setia

Nengah Sudipa, Wayan Redig, Ni Luh Ariani (dkk). 2012. Gendang Beleq Lombok Nusa Tenggara Barat, Balai Pelestarian Nilai Budaya Badung (Bali, NTB, NTT) bekerja sama dengan Pusat Kajian Bali Universitas Udayana Bali, Denpasar.

Oka A Yoeti. 2006. Pariwisata Budaya. Jakarta: Pradnya Paramita.

Page, Stephen. J. 2009. Tourism Management, Managing For Change. UK: Elsevier.

Utama. Rai, Bagus I Gusti. 2017. Pemasaran pariwisata. Yogyakarta: CV ANDI OFFSET

Sedyawati. Edi. 2012. Budaya Indonesia Kajian Arkelogi, Seni, Dan Sejarah. Jakarta: Rajawali Press

Tumanggor, Rusmin. Ridho, Kholis, Nurochim. 2013. Ilmu Sosial Dan Budaya Dasar. Jakarta: Kencana Prenadamedia Group

Yunus, Rasid 2012. Nilai-Nilai Kearifan Lokal Sebagai Penguat Karakter Bangsa Studi Emperis 
Tentang Huyula. Yogyakarta: Deepublish. Lucianancy,Com.2013.https://lucianancy.com/2013/1 0/28/terios7wonders-10-kearifan-lokal-sukusasak-di-desa-sade-lombok/ di akses Februari 2018

Wikipedia.2018.https://id.wikipedia.org/wiki/Peresean .Di akses januari 022018

Dewi, Made. 2013. Pengembangan Desa Wisata Berbasis Partisipasi Masyarakat Lokal Di Desa Wisata Jatiluwih Tabanan Bali.Jurnal Kawistara. Volume 3 Nomor 2, Agustus Hal 129-139

Imanuel, Florentinius. 2015. Peran Kepala Desa
Dalam Pembangunan Di Desa Budaya Sungai Bawang Kecamatan Muara Badak Kab Kutai Kartanegara. Jurnal Ilmu Pemerintahan. Volume 13 Nomor 2 Hal 1182-1196.

Triwardani, Reni. 2014. Implementasi Kebijakan Desa Budaya Dalam Upaya Pelestarian Budaya Lokal. Jurnal Reformasi. Volume 4 Nomor 2.

Yulianto, 2015. Kreasi Seni Sebagai Daya Tarik Wisata Budaya Di Padepokan Bagong Kussudiarjo Yogyakarta. Jurnal Media Wisata. Volume 13, Nomor 1 Mei 2015. 